\title{
EFEKTIVITAS PEMBERIAN TEH DAUN KELOR TERHADAP SIKLUS MENSTRUASI DAN KADAR HEMOGLOBIN PADA REMAJA ANEMIA
}

\author{
EFFECTIVENESS OF MORINGA OLEIFERA TEA ON MENSTRUATION CYCLE \\ AND HEMOGLOBIN LEVEL ON ADOLESCENT IN SIDRAP DISTRICT \\ Wilda Rezki Pratiwi \\ ${ }^{1}$ Prodi DIII Kebidanan STIKES Muhammadiyah Sidrap, Sulawesi Selatan, Indonesia \\ (penulis korespondensi: wildapratiwi06@gmail.com)
}

\begin{abstract}
ABSTRAK
Latar Belakang: Perempuan dalam kehidupannya akan mengalami siklus menstruasi yang terjadi secara periodik sejak menarche hingga menopause. Siklus menstruasi normalnya berlangsung antara 21 - 35 hari dengan rata-rata siklus 28 hari. prevalensi anemia defesiensi zat besi pada remaja putri ditahun pertama menstruasi sebesar $27,50 \%$ dengan rata - rata usia pertama kali mengalami menstruasi pada usia 13 tahun. Tujuan penelitian ini untuk mengetahui efektivitas pemberian teh daun kelor terhadap siklus menstruasi dan kenaikan haemoglobin pada remaja anemia di Kabupaten Sidrap Metode: Jenis penelitian yang digunakan yaitu penelitian kuantitatif dengan menggunakan metode pre eksperimen. Penelitian ini dilakukan dengan rancangan the one group pretest-posttest design.. Pengambilan sampel purposive sampling dengan kriteria inklusi dan eksklusif dengan jumlah sampel 30 remaja anemia.
\end{abstract}

Hasil: Berdasarkan hasil Mann Whitney U test pada siklus menstruasi dengan kategori $\mathrm{Hb}$ sebelum pemberian teh daun kelor menunjukan $p$ value 0,417 , sedangkan siklus menstruasi dengan kategori $\mathrm{Hb}$ setelah pemberian teh daun kelor menunjukan $p$ value 0,82 .

Kesimpulan: Terdapat efektivitas pemberian teh daun kelor terhadap siklus menstruasi dan kenaikan haemoglobin pada remaja yang anemia di Kabupaten Sidrap.

Kata kunci : Teh daun kelor, anemia, siklus menstruasi

\begin{abstract}
Background: Women in their lives will experience menstrual cycles that occur periodically from menarche to menopause. Menstrual cycles normally last between 21 and 35 days with an average cycle of 28 days. the prevalence of iron deficiency anemia in adolescent girls in the first year of menstruation is $27.50 \%$ with the average age of first menstruation at the age of 13 years. The purpose of this study was to determine the effectiveness of giving Moringa leaf tea to the menstrual cycle and increase in hemoglobin level on adolescents in Sidrap District

Method: This research used was quantitative research using pre-experimental methods. This research was conducted with the one group pretest-posttest design. The sampling was purposive sampling with inclusive and exclusive criteria. with a sample of 30 anemic adolescents.

Results: Based on the results of the Mann Whitney U test in the menstrual cycle with the Hb category before giving Moringa leaf tea showed a $p$ value of 0.417, while the menstrual cycle with the Hb category after giving Moringa leaf tea showed that $p$ value of 0.82 .

Conclusion: There is effectiveness in giving Moringa leaf tea to the menstrual cycle and the increase in hemoglobin in anemic adolescents in Kabupaen Sidrap.
\end{abstract}

Key words: Moringa leaf tea, anemia, menstrual cycle 


\section{PENDAHULUAN}

Perempuan dalam kehidupannya akan mengalami siklus menstruasi yang terjadi secara periodik sejak menarche hingga menopause. Siklus menstruasi normalnya berlangsung antara 21 - 35 hari dengan rata-rata siklus 28 hari. Lama menstruasi biasanya $3-5$ hari. Lama menstruasi pada setiap perempuan biasanya tetap. ${ }^{1}$ Berdasarkan data hasil Riset Kesehatan Dasar (Rikesdas) tahun 2010 didapatkan bahwa sebanyak $68 \%$ wanita usia 10- 59 tahun mengalami haid yang tidak teratur - Gangguan menstruasi tersebut berupa gangguan siklus/pola menstruasi, lama menstruasi, serta gangguan lainnya. ${ }^{2}$

Dinegara berkembang penderita anemia defesiensi zat besi dengan $41 \%$ diantaranya wanita tidak hamil. Prevalensi anemia di India sebesar $45 \%$ remaja putri telah dilaporkan mengalami anemia defesiensi zat besi. Di Indonesia masih cukup tinggi. ${ }^{3}$ Angka prevalensi anemia secara nasional pada kelompok umur adalah $21,70 \%$, anemia pada perempuan relatif sangat tinggi $(23,90 \%)$ dibandingkan laki - laki $(18,40 \%) .{ }^{4}$ Pravelensi anemia berdasarkan lokasi tempat tinggal dilaporkan sebanyak $(22,80 \%)$ yang tinggal di pedesaan lebih tinggi dibandingkan diperkotaaan $(20,60 \%) .^{5}$ Prevalensi anemia defesiensi zat besi pada remaja putri ditahun pertama menstruasi sebesar 27,50 \% dengan rata - rata usia pertama kali mengalami menstruasi pada usia 13 tahun. ${ }^{6}$

Kelor (Moringa oleifera Lam) merupakan salah satu tanaman lokal yang telah dikenal berabad-abad sebagai tanaman multiguna, padat nutrisi dan berkhasiat obat. Mengandung senyawa alami yang lebih banyak dan beragam dibanding jenis tanaman lainnya. Menurut hasil penelitian, daun kelor mengandung vitamin A, vitamin $B$, vitamin $C$, kalsium, kalium, besi dan protein dalam jumlah sangat tinggi yang mudah dicerna oleh tubuh manusia. Tingginya kandungan zat besi $(\mathrm{Fe})$ pada daun kelor kering ataupun dalam bentuk tepung daun kelor yaitu setara dengan 25 kali lebih tinggi daripada bayam dapat dijadikan alternatif penanggulangan anemia pada ibu hamil secara alami. Kandungan senyawa kelor telah diteliti dan dilaporkan oleh Ibok Odura W, O Ellis, at all (2008) menyebutkan bahwa daun kelor mengandung besi $28,29 \mathrm{mg}$ dalam 100 gram. $^{7}$

Dalam 100 gram serbuk kelor mengandung banyak asam amino yang disini dapat membantu mencegah terjadinya proses polimerisasi dan presipitasi besi. Selain itu, pada kelor terdapat vitamin $\mathrm{C}$ (asam acrobat) yang merupakan bahan pemacu absorpsi besi sangat kuat yang berfungsi sebagai reduktor yang dapat mengubah feri menjadi fero, mempertahankan $\mathrm{pH}$ usus untuk tetap rendah sehingga mencegah presipitasi besi dan bersifat sebagai monomeric chelator yang membentuk iron-ascorbate chelate yang lebih mudah diserap oleh tubuh. ${ }^{8}$

Anemia dapat mempengaruhi siklus menstruasi perempuan, kadar hemoglobin yang cukup atau tidak anemia akan membantu keteraturan siklus menstruasi. ${ }^{9} \quad$ Sebaliknya apabila terjadi kekurangan zat besi dalam tubuh dapat menyebabkan kadar haemoglobin rendah, yang dapat menimbulkan banyak komplikasi pada perempuan. Hal tersebut terjadi karena rendahnya kadar hemoglobin pada tubuh mengakibatkan kurangnya suplay oksigen ke hipotalamus. ${ }^{10}$

Tanaman Kelor (Moringa Oleifera) merupakan Salah Satu Jenis Tanaman Tropis Yang Mudah Tumbuh Di Daerah Tropis Seperti Indonesia. Tanaman kelor merupakan tanaman perdu dengan ketinggian 7-11 meter dan tumbuh subur mulai dari dataran rendah sampai ketinggian $700 \mathrm{~m}$ di atas permukaan laut. ${ }^{11}$ Komoditas makanan yang mendapat perhatian khusus sebagai nutrisi alami dari daerah tropis bagian kelor dari daun, buah, bunga, dan polong dari pohon ini digunakan sebagai sayuran bernutrisi di banyak negara. ${ }^{12}$ Tujuan penelitian untuk mengetahui efektivitas pemberian teh daun kelor terhadap siklus menstruasi dan kenaikan haemoglobin pada remaja anemia di Kabupaten Sidrap. 


\section{METODE}

Jenis penelitian yang digunakan yaitu penelitian kuantitatif dengan menggunakan pendekatan pre eksperimen. Penelitian ini dilakukan dengan rancangan the one group pretest-posttest design dimana observasi dilakukan sebanyak dua kali, yaitu sebelum dan sesudah eksperimen selama \pm 1 bulan. Lokasi penelitian di Kabupaten Sidrap pada bulan September 2019. Jumlah sampel sebanyak 30 remaja putri yang anemia. Teknik pengambilan sampel dalam penelitian ini adalah purposive sampling yaitu pengambilan sampel berdasarkan kriteria inklusi remaja putri usia 17-24 tahun, remaja yang kadar $\mathrm{Hb}$ 9-10 gr/dl dan kriteria ekslusi adalah remaja putri yang menderita penyakit kronis.

Analisis data dengan menggunakan metode uji statistik yaitu univariat dilakukan untuk variabel tunggal yang dianggap terkait dengan penelitian dan analisis bivariat untuk melihat distribusi beberapa variabel yang dianggap terkait dengan menggunakan Uji Mann Whitney $U$ test (tidak terdistribusi normal).

\section{HASIL}

\section{Analisis Univariat}

Tabel 1. Krakteristik Reponden $(n=30)$

\begin{tabular}{lcccc}
\hline Variabel & \multicolumn{4}{c}{ Kategori Hb } \\
\cline { 2 - 5 } & \multicolumn{2}{c}{ Ringan } & \multicolumn{2}{c}{ Sedang } \\
\cline { 2 - 5 } & $\mathbf{n}$ & $\mathbf{\%}$ & $\mathbf{n}$ & \% \\
\hline Umur & 6 & 20 & 6 & 20 \\
1. 15 Tahun & 8 & 26 & 5 & 16,6 \\
2. 16 Tahun & 0 & 0 & 5 & 16,6 \\
3. 17 Tahun & & & & \\
Indeks Masa Tubuh & 6 & 20 & 5 & 16,6 \\
1. Gemuk & 5 & 16,6 & 5 & 16,6 \\
2. Normal & 3 & 10 & 6 & 20 \\
3. Kurus & & & & \\
FFQ & 9 & 30 & 6 & 20 \\
1. Cukup & 5 & 16,6 & 10 & 33,3 \\
2. Baik & & & &
\end{tabular}

\section{Analisis Bivariat}

Tabel 2. Siklus Menstruasi - Kategori Kadar Hb Sebelum Pemberian Teh Daun Kelor $(\mathbf{n}=\mathbf{3 0})$

\begin{tabular}{lcccccccc}
\hline Variabel & \multicolumn{9}{c}{ Kategori Kadar Hb } & \multirow{2}{*}{$\boldsymbol{\rho}$ value } \\
& Normal & $\%$ & Ringan & $\boldsymbol{\%}$ & Sedang & $\%$ & \\
\cline { 1 - 7 } Siklus Menstruasi & & & & & & & \multirow{2}{*}{0,417} \\
1. Normal & 0 & 0 & 7 & 23,3 & 12 & 40 & \\
2. Tidak Normal & 0 & 0 & 8 & 26,6 & 4 & 13,3 & \\
\hline
\end{tabular}

Berdasarkan Tabel 2 menunjukkan bahwa tidak ada perbedaan kadar hemoglobin sebelum diberikan teh daun kelor. 
Tabel 3. Siklus Menstruasi - Kategori Kadar Hemoglobin Setelah Pemberian Teh Daun Kelor $(n=30)$

\begin{tabular}{lccccccc}
\hline Variabel & \multicolumn{8}{c}{ Kategori Kadar Hb } & Nilai p \\
\hline Siklus Menstruasi & Normal & $\%$ & Ringan & $\boldsymbol{\%}$ & Sedang & $\%$ & \\
1. Normal & 16 & 53,3 & 4 & 1,3 & 5 & 16,6 & 0,82 \\
2. Tidak Normal & 2 & 6,6 & 3 & 10 & 0 & 0 & \\
\hline
\end{tabular}

Berdasarkan hasil uji statistik Tabel 3 menunjukkan bahwa tidak ada perbedaan kadar

\section{PEMBAHASAN}

Pada penelitian ini seorang remaja putri yang mempunyai kadar $\mathrm{Hb}$ dibawah 11,5gr \% disebut menderita anemia. Anemia pada saat remaja atau kekurangan kadar hemoglobin dalam tubuh dapat mempengaruhi atau menyebabkan pertumbuhan yang lambat pada saat remaja dan bisa mempengaruhi siklus menstruasi, hal ini berhubungan dengan perubahan kadar hormone steroid yang merupakan faktor utama dalam pengaturan siklus tersebut. ${ }^{13}$

Kadar Hemoglobin yang cukup atau tidak anemia akan membantu keteraturan siklus menstruasi. Sebaliknya apabila kekurangan zat besi dalam tubuh dapat menyebabkan kadar haemoglobin rendah, yang dapat banyak menimbulkan komplikasi pada perempuan. Hal tersebut terjadi karena rendahnya kadar haemoglobin pada tubuh mengakibatkan kurangnya suplay oksigen ke hipotalamus. ${ }^{14}$

Anemia gizi besi paling banyak di tanggulangi dengan komsumsi zat besi. Hasil penelitian juga mengakui bahwa daun kelor (moringa oliefera) dikenal mempunyai berbagai macam kandungan gizi. Salah satunya adalah zat besi, protein, vitamin A, Vitamin C, kaliun dan kalsium. Daun kelor juga menjadi alternatif untuk pengobatan karena dipercaya mengandung zat antioksidan. ${ }^{15}$

Siklus menstruasi yang tidak normal bisa disebabkan karena wanita mempunyai atau menderita anemia. Anemia membawa pengaruh yang sangat penting untuk keteraturan siklus menstruasi. Wanita yang mempunyai atau menderita anemia sehingga suplay oksigen keseluruh tubuh berkurang Folikel Stimulating Hormone (FSH) dan Luteinizing ( $\mathrm{LH}$ ) yang dihasilkan oleh hipotalamus berpengaruh. ${ }^{13}$

Teh daun kelor adalah teh yang berasal dari daun yang bernama Moringa Oleifera hemoglobin setelah pemberian daun kelor.

berdasarkan berbagai penelitian mampunyai banyak khasiat yang terbukti kebenaranya. Dianggap sebagai minuman ajaib yang sangat bergizi dan manfaatnya telah diakui oleh ahli gizi, ahli diet dan nutrisi kaya akan zat gizi makro dan mikro. ${ }^{12}$ Dalam dosis teh daun kelor dimana setiap kantong terdiri dari 2,5 gr ser buk daun kelor. Adapun pemberian dosis teh daun kelor sebesar 5 gr per hari yaitu 1 kantong teh (2,5 gr) pagi hari dan 1 kantong teh tiap sore hari. Penggunaan dosis daun kelor disesuaikan dengan pertimbangan penelitian yang aman dikonsumsi oleh remaja putri tetapi tetapi mempunyai potensi sebagai sumber oksidan, anti-inflamasi dan nutrisi yang tinggi.

Pemberian teh daun kelor kepada remaja yang anemia dianggap memiliki efektifitas yang cukup tinggi, ini dibuktikan bahwa terdapat peningkatan kadar hemoglobin dan siklus menstruasi menjadi teratur pada remaja yang awalnya menderita anemia dengan siklus menstruasi yang tidak teratur. Daun kelor berguna pada penderita anemia baik dalam dosis rendah dan relatif tinggi. Peningkatan yang signifikan dalam jumlah sel darah merah (eritrosit) dan sel darah putih (leukosit) dengan pemberian daun kelor menunjukan bahwa tidak hanya baik sebagai suplemen makanan tetapi juga obat terutama untuk anemia. ${ }^{16}$

Ekstrak etanol daun kelor memberikan aktivitas analgesic, aktivitas inflamasi. Kandungan senyawa flavonoid dalam daun kelor diduga sebagai senyawa yang memberikan aktivitas antiinflamasi dengan menghambat aktivitas enzim siklooksigenase. Kuersetin yang merupakan golongan flavonoid merupakan komponen bioaktif utama kelor yang memiliki mekanisme sebagai antiinflamasi dan untuk memperlancar siklus haid. ${ }^{17}$ 
Pada penelitian ini juga didapatkan masih adanya responden dengan siklus menstruasi normal tapi masih memiliki kadar haemoglobin yang tergolong ringan dan sedang, sedangkan dengan siklus menstruasi yang tidak normal dengan kadar haemoglobin sedang terdapat 3 orang responden. Ini diperkirakan karena faktor lain yang menjadi penyebab kadar haemoglobin tidak mengalami peningkatan.

Adanya siklus menstruasi yang menyebabkan banyak kehilangan darah, remaja putri yang diet ketat dan lebih banyak mengkomsumsi makanan nabati yang

\section{KESIMPULAN DAN SARAN}

Terdapat efektivitas pemberian teh daun kelor terhadap siklus menstruasi dan kenaikan haemoglobin pada remaja yang anemia di Kabupaen Sidrap. Oleh karena itu perlu dilakukan upaya pencegahan anemia pada

\section{UCAPAN TERIMA KASIH}

Ucapkan terima kasih disampaikan kepada semua pihak yang terlibat dan mendukung dalam kegiatan ini, Untuk ketua LPPM STIKES Muhammadiyah Sidrap yang tidak henti - hentinya memberikan saran dan kritikan selama penyusunan, dr. Bambang

\section{DAFTAR PUSTAKA}

1. Wiknjosastro H. 2012. Ilmu Kandungan. Jakarta : Bina Pustaka Sarwono Prawirohardjo.

2. Santi DR. \& Pribadi ET. 2018. Menstrual Disorders Condition of Patients Treated. Journal Of Health Science and Prevention, 14-21.

3. Fakidah L N \& Putri KSE. 2016. Faktor Faktor yang Berhubungan dengan Status Hemoglobin pada Remaja Putri. Maternal, 60-61.

4. Kemenkes. RI. 2013. Riset Kesehatan Dasar (RISKESDAS). Jakarta .

5. Listiana A. 2016. Analisis Faktor yang Berhubungan dengan Kejadian Anemia Gizi Besi pada Remaja Putri di SMKN 1 Terbanggi Besar Lampung Tengah. Jurnal Kesehatan, 455-469.

6. Priyanto DL. 2018. Hubungan Umur, Tingkat Pendidikan, dan Aktivitas Fisik Santriwati Husada dengan Anemia. Jurnal Berkala Epidemologi, 139-146. kandungan zat besinya sedikit sehinggah kebutuhan zat besi tidak terpenuhi dan asupan gizinya tidak seimbang. Setiap hari manusia kehilangan zat besi 0,6 mg yang disekresi, khususnya melalui feses (tinja). Remaja putri yang mengalami menstruasi tiap bulan akan kehilangan zat besi 1,25 mg perhari, sehingga kebutuhan zat besi lebih banyak dari pria. ${ }^{18}$

Kebutuhan zat besi ini tidak hanya diberikan kepada remaja putri saja akan tetapi dapat juga diberikan pada pekerja wanita untuk meningkatkan kadar hemoglobin. ${ }^{19}$

remaja dengan cara mengkomsumsi makanan yang mengandung zat besi.selain itu perlu dilakukan penelitian lebih lanjut terkait pemberian teh daun kelor dengan jumlah sampel yang lebih besar.

Roesmono, MM selaku ketua STIKES Muhammadiyah Sidrap, Nurjanna, S.ST., M. Keb selaku ketua prodi DIII Kebidanan STIKES Muhammadiyah Sidrap yang telah memberikan masukan - masukan berharganya kepada kami.

7. Mutia, Rahmawati. 2017. Pengaruh Ekstrak Daun Kelor Terhadap Peningkatan Kadar Hemoglobin Ibu Hamil Trimester 2 dan $3 d i$ Puskesmas Semanu I. Yogyakarta : Program Studi Bidan Pendidik Jenjang Diploma IV Fakultas Ilmu Kesehatan.

8. Prihatin DR. 2015. Pengaruh Ekstrak Daun Kelor terhadap Berat Badan dan Panjang Badan Anak Tikus Galur Wistar. Jurnal Ilmiah Rekam Medis dan Informatika Kesehatan. 15-22.

9. Kristianti S \& Wibowo A. 2014. Hubungan Anemia dengan Siklus Menstruasi pada Remaja Putri di SMANegeri 1 Imogiri, Bantul, Yogyakarta ..

10. Hidayati S., Kusumawati E., dkk. 2019. Anemia Defesiensi Besi dan Indeks Massa Tubuh Terhadap Siklus Menstruasi Remaja. Jurnal Kesehatan, 12 (1). 
11. Aminah S., Ramdhan T \& Yanis M. 2015. Kandungan Nutrisi dan Sifat Fungsional Tanaman Daun Kelor (Moringa Oleifera). Buletin Pertanian Perkotaan, 5 (2).

12. Winarno. 2018. Tanaman Kelor( Moringa Oleifera) Nilai Gizi, Manfaat, dan Potensi Usaha. Jakarta : Gramedia Pustaka Utama,

13. Kristianti S., Wibowo TA. 2014. Hubungan Anemia dengan Siklus Menstruasi pada Remaja Putri di SMA Negeri 1 Imogiri, Bantul, Yogyakarta. Jurnal Studi Pemuda, 3(1).

14. Hidayati L, Kusumawati E.,dkk. 2019. Anemia Defisiensi Besi dan Indeks Massa Tubuh Terhadap Siklus Menstruasi Remaja. Jurnal Kesehatan, 12(1).

15. Fauziandara EN. 2019. Efektifitas Ekstrak Daun Kelor Terhadap Peningkatan Kadar Haemoglobin pada Remaja Putri ., Jurnal Kesehatan Karya Husada, 17 (2).

16. Hamdiyah \& Sukarta A. 2019. Pengaruh Pemberian Teh Daun Kelor(Moringa Oleifera Leaves) Terhadap Penurunan Dismenore pada Remaja Putri Anemia di Panti Asuhan sejahtera Aisyiyah Kabupaten Sidrap. Jurnal Antara Kebidanan, 2 (4): 6170.
17. Sulistyawati R, Pratiwi. 2015. Pengaruh Pemberian Ekstrak Etanol Daun Kelor (Moringa Oleifera. L) terhadap Ektivitas Analgesic dan Antiinflamasi melalui Ekspresi Enzim Siklooksigenase. Pharmaciana, 6(1): 31-38.

18. Nuraeni, R.,Sari.P., dkk. 2019. Peningkatan Kadar Hemoglobin Melalui Pemeriksaan dan Pemberian Tablet Fe Terhadap Remaja yang Mengalami Anemia Melalui Gerakan Jumat Pintar., Indonesia Journal of Community Engagement, 5(2): 200-221.

19. Maksuk M, Pratiwi D, Amin M, Suzzana S. 2019Kadar Hemoglobin Pekerja Penyemprot Gulma Akibat Paparan Pestisida Di Perkebunan Kelapa Sawit. JPP (Jurnal Kesehat Poltekkes Palembang).;14(1 SE-Articles). 